\title{
ADMINISTRATIVE BIAS IN SOUTH AFRICA
}

\section{E S Nwauche*}

\section{Introduction}

In South Africa, section 6(2)(a)ii of the Promotion of Administrative Justice Act ${ }^{1}$ provides that it is a ground for judicial review if in taking an administrative action, $^{2}$ an administrator "was biased or reasonably suspected of bias". ${ }^{3}$ This article examines the meaning and application of this ground for review. Bias or reasonable suspicion of bias equates with actual and apparent bias

* Visiting Professor of Law, North West University (Potchefstroom Campus), Potchefstroom, South Africa and Associate Professor of Law, Faculty of Law, Rivers State University of Science and Technology, P.M.B. 5080, Nkpolu Oroworukwo Port Harcourt, Rivers State Nigeria. Contact: nwauche@hotmail.com or drtesn@puk.ac.za.

The author would like to thank Professor Chuks Okpaluba and Eddie Maluleke for comments on earlier drafts of this paper. The usual disclaimer applies.

1 Promotion of Administrative Justice Act 3 of 2000, hereinafter PAJA. PAJA is the legislative compliance with the mandate of $s 33$ of the 1996 Constitution of the Republic of South Africa and provides that everyone has the right to administrative action that is lawful, reasonable and procedurally fair.

2 'Administrative action' is defined as the threshold of every activity that is sought to be governed by administrative law. S 1 of PAJA defines an administrative action as a decision made or a failure to make a decision by an organ of state exercising public power or performing a public function or a natural or juristic person exercising a public power or performing a public function. It is important to note that between 1993 and 2000, when PAJA was promulgated, South African courts were embattled with the interpretation of what an administrative act is. What follows hereafter is an illustration that is no way definitive: President of the Republic of South Africa v South Africa Rugby Football Union (3) 2000 (1) SA 1 (CC): The formulation of policy is not an administrative act; Permanent Secretary, Department of Education and Welfare, Eastern Cape $v$ Ed-U-College (PE) (Section 21) 2001 (2) SA 1: Allocation of appropriate funds to schools is an administrative act; Mkhatswa v Mkhatswa 2002 (3) SA 441 (T), Janse van Rensburg v Minister of Trade and Industry 2001 (1) SA 29 (CC): implementation of legislation is an administrative act; Fedsure Life Assurance Ltd v Greater Johannesburg Transitional Metropolitan Council 1999 (1) SA 1 (CC): the exercising of legislative function is not administrative; Nel $v$ Le Roux 1996 (3) SA 562 (CC), Bernstein v Bester 1996 (2) SA 751 (CC): the performance of a judicial function is not administrative; Transnet v Goodman Bros 2001 (12) SA 853 (SCA): the tender process of government is an administrative act; and Claude Neon $v$ City Council of Germistown 1995 (3) SA 710 (W): an act giving rise to a legitimate expectation is an administrative act.

3 Hereinafter bias ground for review. 
respectively and reflects one of the rules of natural justice, the other being the right to a fair hearing.

It is because no direct judicial interpretation of the bias ground for review has been undertaken by South African courts that I argue in this paper that there is a need for this interpretation and that what is at present applied as the test for administrative bias, namely the reasonable apprehension test enunciated in the case of President of the Republic of South Africa $v$ South African Rugby Football Union (2), ${ }^{4}$ is not suitable for administrators. The reason for this is that it is designed for judicial officers, which is evident in the presumption of judicial impartiality that underpins the test, and the consequently high threshold for the finding of judicial bias. I further contend that the 'reasonable suspicion' test, as interpreted in the cases of BTR Industries South Africa (Pty) Ltd v Metal and Allied Workers Union ${ }^{5}$ and $S \vee$ Roberts, $^{6}$ is suitable for determining administrative bias because it depends on the impression of the reasonable observer in the position of the lay litigant and makes no presumptions, judicial or otherwise. I also argue that this interpretation of the bias ground for review is the one that enables a lower threshold for finding administrative bias. This lower threshold is justified because of the importance of maintaining public confidence in the administration. I review and disagree with decisions in a number of cases where South African courts and administrative tribunals have recognized and advocated the need for a different treatment of administrators, resulting in a higher threshold of bias. I contend that the reasonable suspicion test does not adequate dealing adequately with all ramifications of administrative bias, including the issue of institutional bias and vicarious partiality. Accordingly, I construct a model for determining administrative bias that combines the reasonable suspicion test and the curative mechanism of administrative appeal, as well as some level of judicial review. This is exemplified by the jurisprudence of article 6(1) of the European Convention of

4 President of the Republic of South Africa v South African Rugby Football Union (2) 1999 (4) SA 147 (CC). Hereinafter Sarfu 2.

5 BTR Industries South Africa v Metal and Allied Workers Union (1992) 3 SA 673 (A). Hereinafter BTR Industries.

6 S v Roberts 1999 (4) SA 915 (SCA). Hereinafter Roberts. 
Human Rights, especially in the light of the contemplation of South African Magistrates' Courts as a jurisdictional route for judicial review.

In section two I review the existing jurisprudence for determining administrative bias in South Africa. In this section I examine the concept of actual bias and then consider the two tests of apparent bias, namely the 'reasonable suspicion' test and the 'reasonable apprehension' test. I also determine in this section whether the two tests are the same or differ significantly, and then consider how South African courts have dealt with the issue of institutional bias. In section three I construct a model for administrative bias and then consider the waiver of administrative bias in section four. Concluding remarks appear in section five.

\section{A review of the determination of administrative bias in South Africa}

In this section I review the existing jurisprudence on the determination of administrative bias. Two broad areas are dealt with below. The first is the test for determining administrative bias and the second the issue of institutional bias.

\subsection{The test for administrative bias}

Even though the bias ground for review stipulates bias or reasonable suspicion of bias, the cases examined below show that South African courts employ the reasonable suspicion test and the reasonable apprehension test when determining administrative bias. We shall now examine actual bias and then consider apparent bias. 


\subsubsection{Actual bias}

The nature of the formulation of the bias ground for review seems to contemplate a distinction between actual and apparent bias, even though South African common law does not distinguish between actual and apparent bias as English common law ${ }^{7}$ does. All allegations of bias are subjected to the test for apparent bias, even though conduct that would qualify as actual bias is more likely to be found in such a case. A few examples will suffice.

In Liebenberg $v$ Brakpan Liquor Licensing Board, ${ }^{8}$ the blood relationship between the mayor of a municipality and an applicant who was one of the many applicants competing for a liquor licence before the local liquor licensing board was held by the court to be enough to create a likelihood of bias, especially as the mayor's brother had won the licence. In Rose $v$ Johannesburg Local Road Transportation Board, ${ }^{9}$ the chairman of the Board was also a director of three powerful companies, one of which was the largest operator of taxis in Johannesburg and was opposed to the application which, if granted, would not have been to its benefit. The chairman refused to recuse himself and on review the court held that a reasonable man would apprehend that the chairman was biased.

In Parag v Ladysmith City Council, ${ }^{10}$ the nature of the relevant interest lay in the fact that members of a licensing appeal committee were also holders of a general dealers' licence. A member of a boundary-determining commission was ordered by the court to recuse himself in Peri-Urban Areas Health Board $v$

7 See the case of Dimes v Proprietors of the Grand Junction Canal (1852) 3 HLC 759 where the court held that actual bias exists where a judge is a party to a case or has pecuniary interest in a case. In $R$ v Bow Street Metropolitan Stipendiary Magistrate and others ex parte Pinochet Ungarte (No. 2) [1999] 1 All ER 577, the House of Lords extended this class to non-pecuniary interests where the judges' decision would lead to a promotion of a cause in which the judge was involved with one of the parties.

$8 \quad$ Liebenberg v Brakpan Liquor Licensing Board 1944 WLD 52.

9 Rose $v$ Johannesburg Local Road Transportation Board 1947 (4) SA 272 (W).

10 Parg v Ladysmith City Council 1961 (3) SA 714 (N). 
Administrator Transvaal ${ }^{11}$ when it was established that he was also a member of a firm of consulting engineers who stood to benefit from the extension of the municipal boundaries.

There is no doubt that personal interest of a financial nature will qualify as bias. Whether the non-pecuniary type of personal interest will also qualify will depend on the circumstances of the case. In any event, the stipulation that a reasonable suspicion of bias is enough to ground a review will take care of the cases that may be doubtful as representing actual bias. We now turn to the test for apparent bias.

\subsubsection{The test for apparent bias}

As was stated above, the second limb of the bias ground for review is 'reasonable suspicion of bias'. In this section I intend to establish what this means. I shall first consider the meaning of the reasonable suspicion of bias test to examine the reasonable apprehension test and then determine the difference between the two tests.

\subsubsection{The reasonable suspicion test in South Africa}

The 'reasonable suspicion' test for apparent bias was laid down in the case of BTR Industries. In this case, the Appellate Division stated that:

....in our law the existence of a reasonable suspicion of bias satisfies the test; and that an apprehension of a real likelihood that the decision maker will be biased is not a prerequisite for disqualifying bias. The test is that of a 'reasonable suspicion. ${ }^{12}$

11 Peri-Urban Areas Health Board v Administrator Transvaal 1961 (3) SA 669 (T). See also the case of Bam-Mugwanya $v$ Minister of Finance and Provincial Expenditure, Eastern Cape 2001 (4) SA 12.(ck).

$12 \mathrm{~N} 5$ at p 693. See also Council of Review, South African Defence Force v Monnig 1992 (3) SA 482 (A) (hereinafter Monnig). See also Moch v Nedtravel 1996 (3) SA 1 (A) (hereinafter Moch); De Lille v Speaker of the National Assembly 1998 (3) SA 340 (C); 
The facts in BTR Industries are that in the course of a long drawn-out dispute between labour and the management of a company the President of the Industrial Court participated in a seminar arranged by management's industrial relations consultant in which management's lawyers all presented papers. In Roberts the Supreme Court of Appeal clarified this test. Howie ja said:

The requirements of the test for the appearance of judicial bias are as follows as applied to judicial proceedings: (1) There must be a suspicion that the judicial officer might, not would, be biased. (2) The suspicion must be that of a reasonable person in the position of the accused or the litigant. (3) The suspicion must be based on reasonable grounds. (4) The suspicion is one which the reasonable person referred to would, not might, have. ${ }^{13}$

The court was quick to emphasise that:

....if the suspicion of bias is one based on reasonable grounds the reasonable person would have it. If it were not so founded the reasonable person would not have it. ${ }^{14}$

It is important to note that many years after the Sarfu 2 test had been applied, albeit wrongly, as the test for administrative bias, South African courts and tribunals continue to use the BTR Industries and Roberts test. For example in County Fair Foods $v$ Theron, ${ }^{15}$ the conduct of an arbitration by a CCMA commissioner was held to have raised an apprehension of bias because of the manner in which he descended into the arena in the questioning of the employee. In reaching this decision the Labour Court applied the test in BTR Industries and noted Sarfu $2 .^{16}$

Ighayiya Technical College $v$ Member of the Executive Council for Education, Eastern Cape 1998 (4) SA 502 (Ck).

$13 \mathrm{~N} 6$ at $\mathrm{p} 924$.

14 Ibid at $\mathrm{p}$ 925. Emphasis original.

15 County Fair Foods v Theron [2001] 2 BLLR 134 (LC).

16 See also Afrox Ltd $v$ Lata [1999] 5 BLLR 467 (LC) where the court applied the test in BTR Industries. 


\subsubsection{The reasonable apprehension test}

In Sarfu 2 the Constitutional Court of South Africa adopted the reasonable apprehension test. ${ }^{17}$ In the course of an action instituted in the Constitutional Court against Nelson Mandela, the then President of the Republic of South Africa, an application for recusal was lodged before the Constitutional Court on the grounds that the applicant had a reasonable apprehension that every member of the court would be biased against him, and that he consequently might not get a fair trial. The general allegation made against all the members was that their bias would arise because they had been appointed by President Mandela. Further specific allegations were made against individual members of the court on the basis of personal and political links with Mr Mandela. The court laid down the proper approach to the application of recusal of members of a court. The court stated that:

It follows from the foregoing that the correct approach to this application for the recusal of members of this court is objective and the onus of establishing it rests upon the applicant. The question is whether a reasonable, objective and informed person would on the correct facts reasonably apprehend that the judge has not or will not bring an impartial mind to bear on the adjudication of the case, that is a mind open to persuasion by evidence and the submissions of counsel. The reasonableness of the apprehension must be assessed in the light of the oath of office taken by the judges to administer justice without fear or favour; and their ability to carry out that oath by reason of their training and experience. It must be assumed that that they can disabuse their minds of any irrelevant personal beliefs or predispositions. They must take into account the fact they have a duty to sit in any case which they are not obliged to recuse themselves. At the same time it must never be forgotten that an impartial judge is a fundamental prerequisite for a fair trial and a judicial officer should not hesitate to recuse herself or himself if there are reasonable grounds on the part of litigant for apprehending that the judicial officer, for whatever reasons, was not or will not be impartial. $^{18}$

17 This test has been adopted in Lesotho: Sole $v$ Cullinan [2003] 3 All SA 466 (LesCA). For an analysis of this case, see Okpaluba 2004 TLR 1. It has also been followed in Swaziland. See Minister of Justice v Sapire (civ. App 49/ 2001, 10.6.02 unrep).

$18 \mathrm{Ibid}$ at par 48. The court relied on the decision of the Canadian Supreme Court in R. $v S$. (R.D.) (1997) 118 CCC (3d) 353. 
One of the distinguishing features of the reasonable apprehension test in Sarfu 2 is the presumption of judicial impartiality. ${ }^{19}$ The other feature is that the determination of the bias depends on the court's assessment of alleged evidence of bias, and not on the apprehension or suspicion of the litigant. An examination of the cases of BTR industries and Roberts shows that in none of the cases was the presumption of judicial impartiality used. That a new test ${ }^{20}$ is introduced by Sarfu 2 is evident in SACCAWU $v$ Irvin \& Johnson, ${ }^{21}$ where the Constitutional Court in a majority judgment further explained the test. Speaking about the Sarfu 2 test the court said:

In formulating the test the Court observed that two considerations are built into the test itself. The first is that in considering the application for recusal, the court as a starting point presumes that judicial officers are impartial in adjudicating disputes. As later emerges from the Sarfu judgment, this in-built aspect entails two further consequences. On the one hand, it is the applicant for recusal who bears the onus of rebutting the presumption of judicial impartiality. On the other hand, the presumption is not easily dislodged. It requires 'cogent' or 'convincing' evidence to be rebutted. The second in-built aspect of the test is that "absolute neutrality" is something of a chimera in the judicial context. This is because judges are human. They are unavoidably the product of their own life experiences, and the perspective thus derived inevitably and distinctively informs each judge's performance of his or her judicial duties. But colourless neutrality stands in contrast to judicial impartiality - a distinction the Sarfu decision vividly illustrates. Impartiality is that quality of open-minded readiness to persuasion - without unfitting adherence to either party, or to the judge's own predilections, preconceptions and personal views- that of a civilized system of adjudication. Impartiality requires in short a mind open to persuasion by the evidence and the submissions of counsel; and in contrast to neutrality, this is an absolute requirement in every judicial proceeding... The court in Sarfu further alluded to the apparently double requirement of reasonableness that the application of the test imports. Not only must the person

19 On the presumption of judicial impartiality the Constitutional Court cited with approval, the dictum of Cory $\mathrm{j}$ in the R.V S. (R.D) ibid par 117: "Courts have rightly recognized that there is a presumption that judges will carry out their oath of office... This is one of the reasons why the threshold for a successful allegation of perceived judicial bias is high. However, despite this high threshold, the presumption can be displaced with 'cogent evidence' that demonstrates that something the judge has done gives rise to a reasonable apprehension of bias."

20 See Okpaluba 2003 JJS 109.

21 SACCAWU v Irvin \& Johnson 2000 (3) SA 705 (CC). Hereinafter SACCAWU 1. 
apprehending bias be a reasonable person, but the apprehension must in the circumstances be reasonable... The 'double' unreasonableness requirement also highlights the fact that mere apprehensiveness on the part of the litigant that a judge will be biased - even a strongly and honestly felt anxiety - is not enough. The court must carefully scrutinize the apprehension to determine whether it is to be regarded as reasonable. In adjudging this, the court superimposes a normative assessment on the litigant's anxieties. It attributes to the litigant's apprehension a legal value, and thereby decides whether it is such that should be countenanced by law. ${ }^{22}$

The minority judgment in this case brings into clearer relief the different approaches that are possible in the interpretation of the reasonable apprehension test. The dissenting opinion of Mokgoro and Sachs ij in SACCAWU 1 puts my argument in proper perspective:

The test for recusal places a heavy burden of persuasion on the person alleging judicial bias or its appearance. But despite the presumption in favour of judges' impartiality, the test requires an assessment of the litigant's perception of impartiality... A judge called upon to decide whether or not a disqualifying apprehension of bias exists, however, should consider the apprehension of the lay litigant alleging bias and the reasonableness of that apprehension based on the actual circumstances of the case. As Cameron AJ points out, the lay litigant is assumed to be well-informed and equipped with the correct facts. But the lay litigant should not be expected to have the understanding of a trained lawyer and to appreciate the implications of the different nature of the appeal process. In both cases it will be the judges who decide and who must have an open mind. In all circumstances, the test emphasizes reasonableness in the light of the true facts, not the technical nuances of the particular case. It is our contention that the reasonableness of the apprehension also requires that the judge assess the lay litigant in her or his context. ${ }^{23}$ 
2.1.2.3 A comparison of the 'reasonable apprehension' test and the 'reasonable suspicion' test

In this section we shall determine whether the 'reasonable apprehension' test is the same as the 'reasonable suspicion' test or if they are different, and explain this difference. In Sager $v$ Smith, ${ }^{24}$ the Supreme Court of Appeal held that the use of the word 'apprehension' instead of 'suspicion' is a difference in terminology, which has no significance. In Sager $v$ Smith,${ }^{25}$ the English Court of Appeal stated that in an overwhelming number of cases the practical application of the test of reasonable suspicion and the real danger (similar to the reasonable apprehension test) tests leads to the same result.

It is my opinion that in practical terms there are significant differences between the two tests. The difference between the reasonable suspicion test and the Sarfu 2 test lies in the weight attached to the perception of the lay observer compared to the determination of the court. While the reasonable suspicion test depends on the perception of the lay observer and is therefore grounded in appearance, the Sarfu 2 test hinges on the determination of the court, which relies on reality evident in proof of actual bias. Consequently, the Sarfu 2 test results in a high threshold for finding bias, because the court is unlikely to find bias as it presumes that it is unlikely to be influenced by acts that may ordinarily give rise to the appearance of bias. The Sarfu 2 test deals with reality, which is all about a court's confidence that it will not be influenced.

The reverse is the case with the reasonable suspicion test. The reasonable suspicion test depends on the lay observer's perception, which is far removed from reality. As Dr Malleson argues with respect to the difference between the reasonable suspicion test and the real danger (similar to the reasonable apprehension test) tests:

24 Ibid at par 15.

25 Sager v Smith 2001 (3) SA 1004 (SCA); [2000] 2 WLR 870. 
Despite a certain amount of confusion in the case law over the distinction between the two tests, it is now clear that the key difference is that the latter requires only the appearance of bias, whereas the 'real danger' test requires that there is a likelihood of actual bias... in Locabail the court sought to play down the differences in practice between the 'reasonable suspicion' test and the 'real danger' test, stressing that in an overwhelming majority of cases the application of either test would lead to the same result. This conclusion glosses over the important practical effect of the real danger test in limiting the number of successful claims for disqualification in cases where the court is persuaded that the judge did not know of the matter relied upon as undermining his impartiality. ${ }^{26}$

The reasonable suspicion test therefore enables a lower threshold for finding bias and is therefore more likely to find bias than the Sarfu 2 test.

\subsection{A review of the application of the tests for administrative bias}

The cases considered below stress a lower standard for administrative bias, which is indicative of the fact that administrative officers and tribunals are unable to exercise the same level of competence as judicial officers. A lower standard would make it more difficult to determine administrative bias, because conduct that would have led to a finding of bias would be condoned. Thus a lower standard is akin to the high threshold that the reasonable apprehension test leads to. Using the 'real' apprehension test and a lower standard would result in a situation where it may be impossible to ever find administrative bias. What follows hereafter are three examples of a lower standard for administrative bias. The first example of this is found in the decision of the Supreme Court of Appeal in Commissioner of Competition Commission $v$ General Council of the Bar of South Africa, ${ }^{27}$ where the court decided that the failure of an administrative body to observe the requirements of natural justice in this case - fair hearing - is not always indicative of bias. This case arose out

26 Malleson 2002 Legal Studies 56-57. Emphasis original.

27 Commissioner of Competition Commission v General Council of the Bar of South Africa 2002 (6) SA 606 (SCA). 
of an application brought by the General Council of the Bar in South Africa before the South African Competition Commission. The court explained that:

... the present is but one of the very many cases in which an administrative body has failed to observe a principle which lawyers regard as elementary and it will be a sad day if, whenever this occurs, the body can be accused or suspected of bias. It is unfortunately one of the facts of life that administrative bodies perform their functions with varying degrees of competence. Sometimes, depending mostly on the expertise of their members and staff, they meticulously observe the requirements of natural justice; but often they do not, not because they are biased, but because they are not skilled in administrative law or inexperienced and know no better, or because a particular requirement of natural justice is simply overlooked. Thus the mere fact that audi alteram partem was not observed does not by itself justify an inference of bias. ${ }^{28}$

Even though the principle enunciated by the court is correct, its application to the facts of the case is, with respect, wrong. While it is true that the nonobservance of the audi rule is not indicative of bias, the court ought to have concentrated on the manner in which the administrative body acted ${ }^{29}$ as being critical in this circumstance and the basis of the appearance of bias. The court even acknowledged that at the trial there was a stubborn attitude on the part of members of the commission, who were slow in realising the procedure to be followed in the assessment of the request of the General Council of the Bar and who felt that all that they had to do was allow the General Council of the Bar the opportunity to respond to the comments of the Minister. Indeed, the court said:

Unless there is a change of heart on his part the prospects of the matter receiving proper treatment if it were to be remitted are not good. ${ }^{30}$

Again, here the court was swayed by what had really happened rather than the suspicion that the conduct of the administrative body had given rise to.

28 Ibid par 16.

29 Emphasis supplied.

30 Par 17. 
Another case advocating a different standard for administrative bias is the case of Kwazulu Transport $v$ Mnguni, ${ }^{31}$ where the Labour Court adopted the test in Sarfu 2 and declared:

The test accordingly sets a high threshold for an applicant in a recusal application to meet. Where that threshold is pitched may vary depending on the circumstances of each case and the forum where the application is made. Thus it will be pitched much higher for an appellate bench where the personal attributes, traits and dispositions of each judge is reduced by the collegial nature of such forum. Appellate judges are also entrusted with a higher level of judicial office and also generally more experienced in the craft of judging. For this reason it would be more difficult to have an appellate judge recused than a trial judge. Similarly, adjudicators who are more experienced in labour dispute adjudication would be able to resist an application for recusal more easily than those who are not. The probability of a reasonable apprehension of bias is greater if the adjudicator is less experienced or is imposed by the parties than when the adjudicator is more experienced or chosen by the parties... Even though the test may be pitched at different levels in the hierarchy of the dispute resolution system it remains the same in the sense that an applicant will always have to show, in essence, a reasonable apprehension of bias on the part of a party to the proceedings. $^{32}$

It is submitted that no matter the level of the threshold that is set for administrators, the fact that the test is based on the Sarfu 2 standard would enable administrative officers and tribunals to determine apparent bias from their perception. However, where the BTR Industries and Roberts test is the standard of the reasonable suspicion test, the nature of the administrative tribunal or officer becomes one of the factors in the determination of bias. It is, however, submitted that in practice, the considerations as outlined in Mnguni are often absent in the perception of the party to a case.

Such considerations smack of the presumption of judicial impartiality, which is the hall mark of the Sarfu 2 test. What difference would it have made to the

31 Kwazulu Transport v Mnguni [2001] 7 BLLR 770 (LC). Hereinafter Mnguni.

32 Ibid at 772-773. The facts of this case are that after a commissioner in the Commission for Conciliation Mediation and Arbitration was appointed the applicant applied for his recusal. The applicant contended that his had a reasonable apprehension of bias because the commissioner had represented his employees in litigation against him on three occasions. 
perception of the party to a case if the CCMA commissioner sat with colleagues? Would the applicant have believed that the collegial nature of the tribunal would mitigate the bias of one of the commissioners? Indeed, it is even likely that the applicant may believe that the commissioner will go a long way towards influencing the other members of the panel.

The fact remains that the court applied the BTR Industries and Roberts test even if it noted and adopted the Sarfu 2 test. This approach may in our opinion be a result of the difficulty in understanding the true import of the two tests. The ruling of the commissioner on the application for recusal is indicative of the two approaches. Rather than consider whether there were grounds for a reasonable apprehension, he sought to prove that the nature of the relationship between him and the employees were too far fetched to influence him. It was therefore correct for the Labour Court to have held that the nature of the relationship was such that a party to the case would readily apprehend that he would be biased.

It is interesting that in adopting the Canadian case of R. $v$ S. (R.D.), the court in Sarfu 2 specifically cited with approval the concurring opinion of L'HeureuxDube and McLachlin $\mathrm{jj}^{33}$ to the effect that:

33 N 5 par 32. Canadian jurisprudence differentiates between judicial and administrative officers in the application of the test. Justice Grandpre in Committee of Justice and Liberty $v$ The National Energy Board [1978] 1 S.C.R 369 in a dissenting opinion at p 395 stated that: "The question of bias in a member of a court of justice cannot be examined in the same light as that in a member of an administrative tribunal entrusted by statute with an administrative discretion exercised in the light of its experience and that of its technical advisers... The basic principle is of course the same, namely that natural justice must be rendered. But its application must take into consideration the special circumstances of the tribunal." In Newfoundland Telephone Company Limited $v$ The Board of Commissioners of Public Utilities [1992] 1 R.C.S. 623, the Canadian Supreme Court said: “...there is great diversity of administrative boards. Those that are primarily adjudicative in their function will be expected to comply with the standard applicable to courts... At the other end of the scale are boards with popularly elected members such as those dealing with planning and developments whose members are municipal councillors. With those boards, the standard will be much more lenient." This is the same position in Australia. In Hot Holdings v Creasy [2002] HCA 51, Hanney j, who was part of the majority, was of the opinion that: "While the test for a reasonable apprehension of bias is the same for administrative and judicial decision-makers, its content may often be different. What is to be expected of a judge in judicial proceedings or a decision-maker in quasi-judicial proceedings will often be different from what is expected of a person making a purely administrative decision. One difference arises when the decision-maker is a Minister who is accountable to the Parliament and the 
Although judicial proceedings will generally be bound by the requirements of natural justice to a greater degree than will hearings before administrative tribunals... ${ }^{34}$

...the facts and the discussion in Sarfu 2 clearly do not deal with the extent of the application of the test to administrative officers and tribunals.

The third example of a lower standard finds expression in the consequences of a finding of bias. There is incipient jurisprudence that the finding of administrative bias should not lead to recusal, possibly due to the expense and inconvenience this will involve. This is a clear example of a difference between administrative and judicial bias. In Schulte $v$ Van der Berg, ${ }^{35}$ Conradie j said:

On the other hand, the nature of a complex administrative proceeding like s 418 enquiry is such that it would, in balancing the interests of individuals and the administration often be inappropriate to insist upon the grant of a remedy developed for and suited to judicial-type proceedings. The Court has to engage in a difficult balancing operation between the individual's interests and the effect of recusal on the administration (and other participants in the administration process). Let me now venture upon the balancing act. An application for recusal of a commissioner on account of bias at the commencement of an enquiry would, generally speaking, cause less disruption and would, for that reason, be more favourably considered than an application such as the present one brought towards the end of a long inquiry where the aggrieved examinee has already given most of his evidence. Recusal as a remedy at this stage of the proceedings seems to me singularly inept. ${ }^{36}$

electorate... Thus it will be ordinarily be very difficult to impute bias or reasonable apprehension of bias to the decision of the Minister who has considered all applications on their merits but made it clear that preference would be given to applicants who complied with government policy" (par 70). See also Minister for Immigration and Multicultural Affairs v Jia Leng (2001) 205 CLR 507 (Hereinafter Jia). Kirby j, who dissented in Jia and in Hot Properties, was not ready to concede: "[t]hat simply because of the political character of a Minister's office and consequent accountability to Parliament, he or she was exempted from compliance with the law against bias or from answering to the courts on that ground, if bias could be established by the evidence" (par 128).

34 Par 40. Emphasis supplied.

35 Schulte $v$ Van der Berg and others NNO 1991 (3) SA 717 (C).

36 At p 721. 
Marais j was reluctant to follow the principle enunciated by his brother Judge, requiring further research and deliberation on the matter. However in Absa Bank Limited $v$ Hoberman, ${ }^{37}$ Van Zyl j agreed with Conradie j when he stated that:

...a court should, in deciding whether or not to remove a commissioner appointed in terms of s 418 of the Companies Act, have regard to the totality of the facts and circumstances underlying the competing interests of the parties involved. It should have a discretion not to remove a commissioner if it should not be to the general benefit of all interested parties to do so, even if it is satisfied that there is a perception of bias adhering to the commissioner. ${ }^{38}$

Van Zyl j had in the previous case of Ma-Afrika Groepbelange $v$ Millman ${ }^{39}$ stated that the expense to be incurred and the inconvenience to be suffered in the appointment of a liquidator was a relevant factor in determining whether to remove the liquidator, even when the court was satisfied that he was biased. The expense incurred by a commissioner was not enough to deter Van Zyl j from ordering the replacement of a commissioner appointed under section 418 of the Companies Act.

It is therefore submitted that the Sarfu 2 test and the lower standard being advocated for administrative officers in the application of the Sarfu 2 test are not appropriate for administrative officers. It is the reasonable suspicion test as interpreted to mean the perceptions of a reasonable lay observer that is appropriate, because it enables a lower threshold and an easier finding of bias necessary to maintain public confidence in the administrative system. This is a point I shall return to later.

37 Absa Bank Limited v Hoberman [1997] 2 All SA 88.

38 At p 106.

39 Ma-Afrika Groepbelange v Millman NO 1996 CLR 751 (C). 


\subsubsection{Institutional bias}

The nature of institutional or structural bias is such that there is great merit in the contention that at least the manner in which the test for administrative bias is applied should be different. The nature of the administrative process is often institutionally biased in that in reaching a decision, the relevant body or officer has such an interest in the outcome of that decision that it becomes structurally biased. The critical question is whether the differentiated application would affect the finding of bias.

Even though Lord Goff was insistent in Gough that the same test applies in full measure to administrators, ${ }^{40}$ subsequent cases ${ }^{41}$ and academic commentators argue that the test is different for administrative officers, especially in the case of institutional bias. ${ }^{42}$

In Monnig, the nature of the bias arose from the composition of the court martial of senior defence officers to deliberate on the alleged wrongdoings of the South African Defence Force. The institutional bias lay in the fact that that every empanelled court martial in the circumstances would likely be viewed as biased. The appellants argued that if the allegation of bias was upheld, the wide criminal jurisdiction of the court martial would be destroyed, something it was alleged would be contrary to the intention of parliament. The Appellate Division

$40 R$ v Gough (1993) 2 All ER 724 at 736-737. See also AT/T v Saudi Cable Corporation [2000] 1 Lyold's Law Reports 22 (QB) and R v Gaming Board for Great Britain: Ex parte Beniam and Khaida [1970] QB 417.

41 See $R v$ Hereford and Worster CC, ex $p$ Wellington Parish Council [1996] JPL 573.

42 See De Smith, Woolf and Jowell Judicial Review of Administrative Action 546-548: "Closely related to the doctrine of necessity is that which permits public officials to exhibit certain kinds of bias in the exercise of their judgment or discretion on matters of public policy... The normal standards of impartiality implied in the adjudicative setting cannot meaningfully be applied to a body entitled to initiate a proposal and then to decide whether to proceed with it in the face of objections. What standards should be imposed on the Secretary of State for the Environment when he has to decide whether or not to confirm a compulsory purchase order or clearance order made by a local authority... or to allow an appeal against a refusal of planning permission? It would be inappropriate for the courts to insist on his maintaining the lofty detachment required of a judicial officer determining a lis inter partes. The Secretary of State's decisions can seldom be wrenched entirely from their context and viewed in isolation from the government responsibilities." 
ruled that in cases of institutional bias, the manner to proceed was to hold that the right of recusal existed in favour of the affected citizen requiring the officer(s) to recuse themselves, unless there could be read into the appropriate legislation an express or implied denial of this right. The doctrine of necessity would justify the express or implied denial. ${ }^{43}$ The court noted that in this particular instance, the regular courts of the land had a concurrent jurisdiction with the court martial, and parliament therefore could not be regarded as having sanctioned the institutional bias inherent in the court martial. ${ }^{44}$

In Umfolozi Transport v Minister van Vervoer, ${ }^{45}$ the institutional bias here was that the state tender board could not be expected to be impartial in considering the tender from state owned companies. The court assumed that the reasonable suspicion test was applicable to a non-judicial officer and held that the institutional bias inherent in the state tender board was intended by the provisions of the State Tender Board Act, which did not prohibit the tender board from considering tenders by companies owned by the state.

Professor Devenish criticizes the judgment and argues that:

The difficulty with the judgment is the question posed by the judge. Surely the appropriate question is not whether the legislature intended the board to have the relevant competence, but whether the relevant rule of natural justice was expressly or by clear implication excluded or limited by the legislature. ${ }^{46}$

He equally points out an important step in the consideration that is introduced by the 1996 Constitution. He argues that:

Where, however, a statute by express words or necessary implication excludes the rule against bias, then such exclusion would

43 The court adopted the opinion of De Smith Judicial Review of Administrative Action 276: "An adjudicator who is subject to disqualification at common law may be required to sit if there is no other competent tribunal or if a quorum cannot be formed without him. Here the doctrine of necessity is applied to prevent a failure of justice."

44 See also Loggenberg v Roberts 19921 SA 393 (C); Dumbu v Commissioner of Prisons 19921 SA 58 (E); Ciki v Commissioner of Correctional Services 1992 (2) SA 269 (E).

45 Umfolozi Transport v Minister van Vervoer [1997] 2 All SA 548 (A).

46 Devenish 2000 TSAR 397, 415. 
have to be compatible with the provisions of the limitation clause set out in section 36 of the constitution, which states that the restriction to the right to just administrative action must be reasonable and justifiable in an open society based on human dignity, equality and freedom... ${ }^{47}$

Another recent case of institutional bias is Financial Services Board $v$ Pepkor Pension Fund, ${ }^{48}$ where it was alleged that the closeness of the relationship between the Registrar of Pension Funds and the Financial Services Board (FSB) was such that any tribunal of which a member of the FSB was also a member could not be impartial. The contention was that the Financial Services Appeal Board was a partial tribunal because it had as its members the Registrar and a member of the FSB. The court construed the relevant acts and held that the relationship between the FSB and the Registrar were not close, as the board had no power to override the decision of the Registrar and held that the test is whether:

...a substantial number of reasonable and informed users of the Appeal Board would think that there was a risk of partial decisions being made because of the one member's connection with the Board and the Board's relationship with the Registrar... I conclude therefore that the presence of a member of the Board does not taint the structure and composition of the Appeal Board. It is my judgment, an independent tribunal as envisaged by section 34 of the Constitution. ${ }^{49}$

The court was mindful of the inevitability of institutional bias when it said:

...it would wreck havoc with our system of administrative adjudication if internal appeals to a higher authority within the same hierarchy were to be impermissible simply because a member of the appeal tribunal has some measure of general supervision or control over the conduct of a member of a lower tribunal. ${ }^{50}$

47 Ibid.

48 Financial Services Board v Pepkor Pension Fund [1998] 4 All SA 129 (C). Hereinafter Financial Services Board.

49 Ibid at $\mathrm{p}$ 136. See also Freedom of Expression Institute $v$ President of the Ordinary Court Martial 1999 BCLR 261(C).

50 Ibid at $\mathrm{p} 136$. 
With due respect it is the reasonable suspicion that the institutional and structural links may lead to partiality that makes the issue of importance. It is noteworthy that rather than proceed to an examination of the issues as laid down in Monnig by seeking to find out if the legislature expressly or impliedly intended the curtailment of the right of recusal that arises in the cases of institutional bias, the court determined the nature of the relationship between the board and Registrar and then applied the reasonable apprehension test. The framework of the court's decision was to identify the independence of the court as a means of making a finding of the impartiality of the court, especially as the question of institutional bias is involved. The court adopted the dictum of Lamer cjc in the Canadian case of $R v \operatorname{Lippe}^{51}$ that:

The overall objective of guaranteeing judicial independence is to ensure a reasonable perception of impartiality. ${ }^{52}$

The court said of the dictum of Lamer cjc:

He is speaking here not of apprehension of subjective bias but of apprehension of bias on an institutional level. The test for this kind of bias is stated in Lippe's case... to be whether, having regard, inter alia, to the parties who appear before a decision maker, a fully informed person would harbour a reasonable apprehension of bias in a substantial number of cases. ${ }^{53}$

It is clear that even though the words 'reasonable apprehension' are used, it is far more akin to the BTR Industries and Roberts test than the Sarfu 2 test. Ross $\mathrm{Kriel}^{54}$ describes the court's reasoning as one which seeks to justify the institutional bias and it is submitted that he is correct.

$51 \quad R$ v Lippe 5 CRR (2d) 31.

52 At p 52. Per Lamer cjc.

$53 \mathrm{~N} 48, \mathrm{p} 135$.

54 See Kriel 1999 Annual Survey of South African Law 73. 


\section{$2.3 \quad$ Vicarious partiality}

An interesting dimension of administrative bias that is quite akin to institutional bias is the concept of vicarious partiality. Even though there is no decided South African case on the matter, there is no doubt that it will emerge in due course because it is a critical feature of all administrative systems. Vicarious partiality occurs when an impartial head of an institution on the advice and recommendation of partial subordinates makes a decision. The question becomes whether the decision is biased. This was what confronted the Australian High Court in Hot Holdings Pty Ltd $v$ Creasy. ${ }^{55}$

In this case, competing applicants applied for an exploration licence and made their presentations in public before the mining warden. After hearing their arguments the warden published his recommendations and his reasons. On the basis of a ballot the warden recommended that the appellant's application be given priority. The warden forwarded his recommendation to the Minister for Mines, who subsequently took representations on the merits of the respective applications from interested persons and took advice from within his department. The departmental advice was contained in a minute and was signed by the Director General of the Department of Minerals and Energy of Western Australia. After a series of deliberations the Minister approved the Director General's recommendation.

The first respondents, who were competing applicants, sought an order of certiorari quashing the Minister's decision on the basis that the decision by the Minister gave rise to a reasonable apprehension of bias. The alleged bias was the pecuniary interest of two officers of the Department who had been involved in the process within the Department that had led to the Director General's advice to the Minister. Specifically, the interest was the holding of shares in a listed public company, which had an option to purchase an $80 \%$ interest in the exploration licence if it were granted to the company that won the exploration 
licence. One of the officers involved directly held shares in the company, while the son of the other officer held the shares.

The latter officer deliberated with the Director General to arrive at the decision that the department should advise the Minister to accept the warden's recommendation. In addition, the other officer was present at the meeting and was asked to prepare the minutes, even though evidence was led to show that he did not participate in the deliberations. A subordinate officer prepared the minutes and it was presented to the Director General, who made some corrections before it was forwarded to the Minister. It was not contested that neither the Minister nor the Director General had any personal or pecuniary interest in the matter. It was also clear that the Minister did not know of the shareholdings of officers or the part they played in the processes leading to the advice.

The majority of the High Court of Australia ${ }^{56}$ held that the impugned decision was that of the Minister who was the decision-maker, and he had no interest such as might give rise to a reasonable apprehension of bias on his part; he had no knowledge of the shareholdings of the officers and there is no ground to apprehend that he might have been influenced by a desire to promote their interests. The court agreed that the only ground for setting aside the Minister's decision was on the ground of procedural unfairness, in that the exercise of the statutory power by the Minister had not been fair because of the presence of bias. The court further held that if the form of unfairness alleged was the actuality or the appearance of disqualifying bias, and that was said to result from the conduct or circumstances of a person other than the decision-maker, then the part played by that other person in relation to the decision would be important. 
The court therefore held ${ }^{57}$ that neither officer had played a central role in the decision-making process as they had made no significant contribution to the Minister's decision and therefore their financial interest did not deprive the Minister's decision of the appearance of impartiality. Hanney j formulated what can be taken to be a test of this dimension of administrative bias:

A court will not conclude that there was a reasonable apprehension of bias merely because a person with an interest in the decision played a part in advising the decision-maker. The focus must be on the nature of the adviser's interest, the part that person played in the decision-making process and the degree of independence observed by the decision-maker in making the decision. If there is a real and not a remote possibility that a Minister has not brought an independent mind to making his or her decision, the role and interest in the outcome of his or her officers may result in a finding of a reasonable apprehension of bias... Thus, the role played by an adviser is a critical factor in determining whether the interest of an adviser in the outcome of a decision taints the decision with bias or a reasonable apprehension of bias. ${ }^{58}$

The Supreme Court of Western Australia, whose decision the High Court overturned, dwelt on the apprehension of bias that the financial interest of the officer would give rise to, irrespective of the fact that the officer may not have

57 The court adopted the decision of the Supreme Court of Canada in Baker v Canada (Minister of Citizenship and Immigration) [1999] 2 SCR 817. In this case an immigration officer who made a decision relied on the recommendation of a subordinate officer, who had examined the case and made detailed notes and comments and expressed opinions strongly adverse to the applicant. The court found that the notes and comments gave rise to an apprehension of racial and other forms of bias. L'Heureux-Dube, who gave the decision of the court, said: "Procedural fairness also requires that decisions be made free from a reasonable apprehension of bias by an impartial decision maker. The respondent argues that Simpson J was correct to find that the notes of the [subordinate officer] cannot be considered to give rise to a reasonable apprehension of bias because it was [the superior officer] who was the actual decision-maker, who was simply reviewing the recommendation prepared by his subordinate. In my opinion, the duty to act fairly and therefore in a manner that does not give rise to a reasonable apprehension of bias applies to all immigration officers who play a significant role in the making of decisions, whether they are subordinate reviewing officers or those who make the final decision. The subordinate officer plays an important part in the process and if a person with such a central role does not act impartially, the decision itself cannot be said to have been made in an impartial manner. In addition... the notes of [the subordinate officer] constitute the reasons for the decision, and if they give rise to a reasonable apprehension of bias this taints the decision itself." At $\mathrm{p} 849$.

$58 \quad$ N 31 par 72. 
had any significant part in the decision making process. ${ }^{59}$ The lower court urged that it is the appearance that matters and not the reality, which was painstakingly pointed out by the majority in Hot Holdings. Kirby j, who was the sole dissenter, mirrored the framework of the Supreme Court of Western Australia when he said:

The question is not one of fine analysis. Instead, it is whether, looking at this decision by the Minister, and the participation in the steps that led to it of the two senior officials of his department, a reasonable member of the public might conclude that there is a real possibility that the decision could have been affected by the earlier participation in it of officers who, personally or through their immediate families, had undisclosed interests of which they were aware and these interests would be advanced if the Minister accepted the departmental recommendation. ${ }^{60}$

Thus, while the whole court agreed that the reasonable apprehension test is applicable to administrative officers, the difference lay in the interpretation and application of that test. While the majority believed that the content should be guided by the nature of the function to be performed, Kirby $\mathrm{j}$ held that the perception of the public is critical.

59 Glesson cj, ibid, par 13 reproduced the opinion of Sheller aj, whose judgment was agreed on by the full court: "In my opinion, the holding by an officer in the Department who had taken part, albeit at the periphery, in the giving of advice to grant an exploration licence on which the Minister acted, of an undisclosed share interest in a company with a direct interest in the grant of an exploration licence must give rise to a reasonable apprehension or suspicion on the part of a fair-minded and informed member of the public that the Minister, acting on or taking into account of such advice, which he believed was impartial, but which it could fairly be suspected was not, had himself for this reason not acted impartially." The court agreed that the interest of the man whose son held the shares may not be disqualifying bias but that it strengthened the suspicion of the public.

60 Par 132. Emphasis original. At par 145 he was more descriptive of the nature of the preferred interpretation of the apprehension: "The reasonable member of the public has neither the time nor the inclination to evaluate the detailed evidence and protestations such as have been made in this case. He or she, as a lay-person, simply sees a ministerial minute in which two senior departmental officers participated without declaring personal or familial pecuniary interest known to each of them. The ultimate decision is to be made by the Minister in the exercise of a largely unguided discretion." In Jia, n 31 he said: "Being concerned primarily with the impact of events upon the persons affected and upon reasonable members of the public, what is involved is the general impression derived from the evidence, not a lawyers fine verbal analysis" at 552. 
The interpretation favoured by the BTR Industries test is far more in accordance with the minority opinion of Kirby $\mathrm{j}$ in Hot properties. It is therefore submitted that this should be an adequate standard to deal with issues of vicarious partiality if it does arise in South Africa.

To conclude this section, it is my opinion that even though the BTR Industries and Roberts test is far more appropriate in identifying administrative bias than the Sarfu 2 test, it is deficient in some respects. It is because of this deficiency that there may be a need to explore some additional steps that could serve to contain bias, because they would operate after the administrative officer or tribunal had reached a decision tainted with bias. Accordingly, in the next section I construct a model for dealing with administrative bias that combines the BTR Industries and Roberts test and the curative powers of administrative appeal and judicial review.

\section{A model for administrative bias in South Africa}

As stated above, I shall construct a model for assessing administrative bias in South Africa that combines the application of the test for bias as determined in the preceding section, the curative effect of administrative appeal and the curative effect of judicial review as exemplified by the jurisprudence of article 6(1) of the European Convention on Human Rights. This model is important in order to adequately provide a consistent basis for determining administrative bias. This model hinges on the use of the reasonable suspicion test, which enables a lower threshold of bias and consequently imposes a higher standard of conduct on administrators. It recognises, however, that even though an administrator may be regarded as biased, there should be curative possibilities, either through an administrative appeal or judicial review. This is especially true of institutional bias. It is to a consideration of this model that I now turn. 


\subsection{The curative powers of judicial review}

Article 6(1) of the European Convention on Human Rights ${ }^{61}$ provides that:

In the determination of his civil rights and obligations or of a criminal charge against him, everyone is entitled to a fair hearing and public hearing within a reasonable time by an independent and impartial tribunal established by law.

It is submitted that the article 6(1) jurisprudence is suitable for South African administrative law, especially as Magistrates' Courts are contemplated as part of the courts ${ }^{62}$ to undertake judicial review. ${ }^{63}$ The jurisdiction of the Magistrate's Court to undertake judicial review is to be a general one or in respect of a specified class of administrative actions as designated by the Minister of Justice. $^{64}$

In $R$ (Alconbury) $v$ Secretary of State ${ }^{65}$ the House of Lords interpreted article 6(1) of the European Convention on Human Rights and held that a case of institutional bias can be cured by the fact that the decision is subject to judicial review. In that case, it was contended that certain statutory powers of the Secretary of State in relation to planning matters, compulsory purchase, railways and highways were incompatible with article 6(1) of the European Convention for the Protection of Human Rights. The decisions of the Secretary of State were subject to judicial review, but not to appeal.

The complaint against the Secretary of State was that when the Secretary of State took a decision instead of an inspector appointed by him, the Secretary of State's role in making policy meant that he had such an interest in the decision that he could not be regarded as an independent and impartial tribunal. The

61 For a general account of this jurisprudence, see Forsyth 2001 CLJ 449.

62 The other courts are the Constitutional Court and the High Court.

63 The definition of 'court' in PAJA is substituted by s 1 of the Promotion of Administrative Justice Amendment Act 53 of 2002.

64 S 9A of PAJA inserted by Act 53 of 2002.

$65 R$ (Alconbury) v Secretary of State [2001] 2 All ER 92. Hereinafter Alconbury. 
Divisional Court ${ }^{66}$ upheld the complaints, holding that the availability of judicial review proceedings was not sufficient to render the impugned provisions compatible with article 6(1). The House of Lords held that some administrative decisions affecting civil rights were taken by ministers answerable to elected bodies, and that where such decisions were subject to review by a court, regard had to be paid to both stages of the process.

Thus, although the Secretary of State was not himself an independent and impartial tribunal in certain cases of the exercising of his powers, the crucial question was whether there was sufficient judicial control to ensure determination by such a tribunal subsequently. ${ }^{67}$ The court held that the jurisprudence did not require such a control to be by way of appeal on facts or merit. What was required was that there should be a sufficient review of legality of the decisions and procedures followed. The Lords further held that the judicial review jurisdiction of the High Court constituted such a review.

The court based its decision on the jurisprudence of the European Court of Human Rights in the case of Bryan $v U K^{68}$ in assessing the sufficiency of the review available to the High Court:

66 After acknowledging that the English common law required a different standard for administrators, the Divisional Court held that article 6(1) of the Convention had changed the position: "But the question we have to ask is whether the position under domestic law can withstand the unqualified procedural right conferred by art. 6 . We do not think it can. The common law approach has inevitably been determined by the constraints imposed by legislation. The logic is that if legislation vests a decision in a person who is biased or provides for a decision to be taken in a manner which is not compatible with the requirements of independence and impartiality, no breach of the requirements of fairness could be found. Such requirements of fairness as there may be must be accommodated to the relevant statutory scheme. But the question now is not how art. 6 can best be accommodated in the interests of fairness given the existing statutory scheme, but rather whether the scheme itself complies with art 6 . To accept that the possibility of the common law bias is inherent in the system and mandated by parliament is merely to admit that the system involves structural bias and requires determinations to be made by a person who is not impartial. It must follow from these conclusions that the Secretary of State is not impartial in the manner required by art 6 because in each case his policy is in issue. This is not to say that there is anything wrong with his role as a policy maker. What is objectionable in terms of art 6 is that he should be the judge in his cause where his policy is in play. In other words he cannot be both policy maker and decision taker." p 955 (par 85-86).

67 See Albert $v$ Belgium (1983) 5 EHRR 533.

68 Bryan v UK (1995) 21 EHRR 342. 
$\ldots$ it is necessary to have regard to matters such as the subject matter appealed against, the manner in which that decision was arrived at, and the content of the dispute, including the desired and actual grounds of appeal. ${ }^{69}$

The principle in Alconbury was also applied in Runa Begum v Tower Hamlets London Borough Council, ${ }^{70}$ where the claimant presented herself to the defendant local housing authority as a homeless person. The authority informed her that it owed her a duty under section 193 of the Housing Act to ensure that accommodation was available to her. In discharge of that duty the authority offered her a secure tenancy of a flat but she turned it down, claiming that the property was unsuitable. Consequently and pursuant to statutory provisions, the claimant requested an internal review of the authority's decision to offer her that accommodation. An officer of the authority, who rejected the claimant's reasons for refusal as unreasonable, conducted the review.

The claimant disputed the factual findings that were the basis of the reviewing officer's decision and appealed to the county court, under section 204(1) of the 1996 Act, which permitted appeal on points of law. The judge quashed the decision, holding inter alia that the authority's failure at least to give consideration to referring a review decision, which turned on questions of disputed fact, to an impartial tribunal wholly independent of the authority was incompatible with the claimant's right under article 6(1) of the European Convention to have her 'civil rights' determined by an 'independent and impartial tribunal'.

The Court of Appeal allowed the appeal and the claimant appealed to the House of Lords, which was required to determine whether the reviewing officer constituted 'an independent and impartial tribunal' for the purposes of article 6(1) and if not, whether the county court, on appeal under section 204 of the 1996 Act, possessed 'full jurisdiction' so as to guarantee compliance with article

69 At p 360-361.

70 Runa Begum v Tower Hamlets London Borough Council [2003] 1 All ER 731. Hereinafter Runa Begum. See also Adan v Newham London Borough Council [2002]1 WLR 2120. For an analysis of this case see Forsyth 2003 CLJ 244. 
6(1), given that section 204 enabled the county court to examine questions of law. The House of Lords held that the reviewing officer did not constitute an 'independent and impartial tribunal' for the purposes of article 6 of the convention, because as an employee whose personal impartiality could not be doubted, she was not independent of that authority when deciding whether the authority had discharged its admitted duty to the claimant. The court further held that the right of appeal under section 204 was sufficient to satisfy article 6(1), because the jurisprudence of the European Court of Human Rights provided compelling support for the conclusion that for reasons of good administration, the absence of a full fact-finding jurisdiction in the county court to which appeal lay from an administrative decision-making body did not disqualify that tribunal for the purpose of article 6 .

Lord Hoffman further explained the contemplation by the European Court of Human Rights of administrative decisions as part of "civil rights" ${ }^{\text {"1 }}$ and what that had necessitated in the form of the curative appeal or review body:

... from an early stage the Strasbourg Court has recognized that the extension of article 6 into administrative decision making has required ... substantial modification of the full judicial model... It has said first, that an administrative decision within the extended scope of article 6 is a determination of civil rights and obligations and therefore prima facie has to be made by an independent tribunal. But, secondly, if the administrator is not independent (as will virtually be the case), it is permissible to consider whether the composite procedure of the administrative decision together with a right of appeal to a court is sufficient. Thirdly, it will be sufficient if the appellate (or reviewing) court has 'full jurisdiction' over the administrative decision. And fourthly as established in the landmark case of Bryan $v$ United Kingdom ...full jurisdiction does not necessarily mean jurisdiction to re-examine the merits of the case, but as I said in Alconbury... 'jurisdiction to deal with the case as the nature of the decision requires'. It may be that the effect of Bryan is ...administrative action falling within article 6 (and a great deal of administrative action still does not) should be subject to an

71 See the case of Ringesien $v$ Austria (No 1) (1971) 1 EHRR 425 and Deumeland $v$ Germany (1986) 8 EHRR 448; Salesi v Italy (1993) 26 EHRR 187; Mennitto v Italy (2002) 34 EHRR 1122: A 6(1) extends beyond private law disputes in the traditional sense of between individuals to all proceedings which are decisive of private rights and obligations. 
examination of its legality rather than its merits by an independent and impartial tribunal. ${ }^{72}$

The House of Lords accordingly interpreted the county court's review jurisdiction on the lawfulness and fairness of the council's action as satisfying the requirement of full jurisdiction. In Bryan a planning inspector dealt with the issue of whether buildings erected in the Green Belt could be considered from their appearance and layout to have been designed for the purposes of agriculture. This was a question of fact and degree. The European Court of Human Rights ruled that the planning inspector was not an 'independent or impartial' tribunal for the purposes of article 6(1). But it also held that the jurisdiction of the High Court was sufficient to comply with article 6(1), even though it could not substitute its own decision for that of the inspector - a critical feature of review - it was bound to satisfy itself that his conclusions were neither perverse nor irrational.

Even though there were undisputed primary facts, the issue for the review of the court were the conclusions drawn from those facts. The court held that such an approach to questions of fact was a feature of the systems of judicial control of administrative decisions of the Member States of the Council of Europe and held that such an approach is reasonable in 'specialised areas of the law'.

In Rita Begum the House of Lords held that the distribution of welfare benefits qualified as a specialised area of the law. In the court's opinion the appeal on points of law enabled the court to assess the reasonableness of the rejection of the provided accommodation by the applicant, which the county court could undertake even if there were incidental disputes of fact.

Given the similarity between article 6(1) of the European Convention and section 34 of the Constitution of the Republic of South Africa, ${ }^{73}$ it is submitted

72 Ibid, par 31-34.

73 S 34 of the 1996 Constitution provides that: "Everyone has the right to have any dispute that can be resolved by the application of law decided in a fair public hearing before a court of law or, where appropriate, another independent and impartial tribunal or forum." 
that the jurisprudence of the former should be of persuasive authority to South African courts. On the one hand there is no doubt that judicial review of administrative action is not conceived in the same manner as in the English system, which requires lower courts to review decisions of administrators, which can then be appealed to the regular courts. The powers granted magistrates in South Africa could be designated in such a way that a review of the facts of the case for procedural fairness would satisfy the constitutional requirement of section 34 . The advantage of this position is that it would be limited to cases of bias, so that the courts would not be flooded with cases and furthermore the Magistrate's Court would only be concerned with the administrative procedure and not the merits. Finally, it would reduce the instances of judicial review before the High Court and the Constitutional Court as contemplated by PAJA. It is also important to point out that the challenge of this type of judicial review is to carefully circumscribe the type of administrative bias that could qualify. Cases of institutional bias or vicarious partiality would be good examples.

\subsection{The curative power of administrative appeal}

Given the different levels of the administrative structure in all legal systems, it is attractive to argue that issues of administrative bias can be cured by appeal within the administrative system. The Appellate Division in Monnig was urged to hold that the hearing of the Council of Review effectively cured the institutional bias in the court martial. It declined to do so. The court noted that in Turner $v$ Jockey Club of South Africa, ${ }^{74}$ the opinion of Megarry j in Leary $v$ National Vehicle Builders ${ }^{75}$ that:

$\ldots$ if the rules and the law combine to give the member the right to a fair trial and the right of appeal, why should he be told that he ought to be satisfied with an unjust trial and a fair appeal ... ${ }^{76}$

74 Turner $v$ Jockey Club of South Africa 19743 SA 633(A). Hereinafter Leary.

75 Leary $v$ National Vehicle Builders [1970] 2 All ER 713 (Ch).

76 Ibid at p720. 
... had been trimmed and corrected by the Privy Council and the House of Lords in the cases of Calvin $v$ Carr $^{77}$ and Lyold $v$ McMahon $^{78}$ respectively, but declined to be persuaded by the new thinking because it involved principles enunciated in the field of proceedings of domestic tribunals of an unincorporated association which were unsuitable for a court martial. The court considered that even though composed of laymen, the court martial was akin to a court of law. It was therefore possible that, had the body in question not been adjudicatory, the Appellate Division may have been persuaded to adopt a curative principle.

However, in Slagment v Building, Construction and Allied Workers' Union ${ }^{79}$ the majority ${ }^{80}$ of the same Appellate Division agreed that an administrative appeal could under certain circumstances cure an initial lack of fair hearing. The circumstances in this regard would be a case where there is no adjudication before the action is taken and there is a full and fair hearing on appeal. The court would have come to a different decision had there been adjudication at the first tier. ${ }^{81}$

The facts of the case are that two employees who insisted on being heard together in a disciplinary hearing were dismissed after being given 45 minutes' notice. The court held that this was procedurally unfair but that a subsequent hearing before another manager when they had had 12 days to reflect on their conduct and had sought advice was enough to cure the defect. Smallberger ja,

77 Calvin v Carr [1979] 2 All ER 440 (PC). At p 447 Lord Wilberforce said: "(T)heir Lordships recognize and indeed assert that no clear and absolute rule can be laid down on the question whether defects in natural justice appearing at an original hearing, whether administrative or quasi-judicial can be 'cured' through appeal proceedings. The situations in which this issue arises are too diverse, and the rules by which they are governed are so various, that this must be so."

78 Lyold v McMahon [1987] 1 All ER 1118 (HL).

79 Slagment $v$ Building, Construction and Allied Workers' Union 1995 (1) SA 742. Hereinafter Slagment.

80 Nicholas aja, Hoexter ja, Grosskopf and Niebnaar ja in the majority. Smallberger ja differed inter alia on the question of the curative effect of the administrative appeal.

81 The court distinguished the factual situation in Leary, where it stated that the observation of Megarry j was made in the context of "domestic and administrative two-tier adjudicatory systems... the present is not the case". Ibid at p 756. 
who differed from the majority, argued that the effect of the lack of an initial hearing on the dismissed employees is to place ...

...the burden of displacing an adverse decision... which for lack of natural justice (procedural unfairness) ought not to have reached. ${ }^{82}$

Even though given in the context of a lack of a fair hearing, it is possible to extend the opinion of the minority in Slagment to the issue of bias. Accordingly, it is submitted that the effect of the breach of natural justice, in this case bias, could be the determinant of the curative ability of the administrative appeal. If the absence of bias in the original administrative proceeding is such that an undue burden would be placed on the individual, the appeal should not be curative. One clear instance of such a burden is when the review is on the record and does not involve a complete rehearing. ${ }^{83}$ It may be far easier to prove that the appeal is curative if it is a review enabling a de novo hearing. It may be possible to also argue that the presence of an administrative appeal could be curative because that administrator was not biased or reasonably suspected of bias.

The principle of curing by administrative appeal would not conflict with the bias ground for review. Indeed it will complement it in the sense that it will enable an interpretation that would seek to establish whether the existence of an impartial higher administrative officer would lead the reasonable observer to agree that there was no reasonable suspicion of bias.

82 Ibid at $\mathrm{p}$ 761. His Lordship agreed that in exceptional circumstances, an administrative appeal could cure a defective initial hearing. It was, however, made clear that this would not be in the circumstances where the lack of a fair hearing is the fault of the dismissed persons. The minority stated that, in this case, the lack of a fair hearing was not the fault of the employees. See also Slade v Pretoria Rent Board 1943 TPD 131.

83 See Slade $v$ Pretoria Rent Board, ibid, at p 137-138. 


\section{$4 \quad$ Waiver of administrative bias}

The nature of the administrative process is such that citizens can be taken to waive their right to an impartial decision by administrative officers and tribunals. Public administration seems to contemplate this and in a sense it may be that citizens have no choice other than to embrace an administrative process that offers no alternative. It is valid to argue that the constitutional requirement of administrative impartiality is illusory given the widespread possibility of institutional bias. Indeed it may well be that PAJA contemplated the individual administrator without considering how institutions are relevant in this regard. The argument for waiver is indeed serious and may be counterproductive because of the fact that citizens may not have any choice as to how their administrative issues are handled. To further regard them as having waived this right may indeed be too much because of the inevitability of their action. It is therefore submitted that a waiver in such circumstances will indeed be unreal and unfair. The situation would be different if a citizen has a choice as to the administrator or institution. A selection in this regard could then be regarded as a waiver.

It is further submitted that PAJA's requirement of a reasonable suspicion of bias as the standard may do away with the question of waiver. At all times what is relevant is how the administrator or agency is perceived. It may well be that participation by the citizen in the process may assist the court in reaching a decision that there is no reasonable suspicion of bias.

\section{$5 \quad$ Concluding remarks}

It is hoped that the South African Constitutional Court will at the earliest opportunity interpret the provisions of section 6(2)a(ii) of PAJA in a manner that reinforces the BTR Industries and Roberts test. This will ensure that finding administrative bias is dependent on the reasonable lay observer and not on the determination of the tribunal, which is the hallmark of the Sarfu 2 test. The BTR 
Industries and Roberts test reduces the threshold for the finding of bias and thus ensures the strengthening of public confidence in the administrative structures of the State.

It is also my view that the incipient trend by the lower courts in South Africa to regard administrative officers as deserving a different treatment in the determination and application of the reasonable apprehension tests is reason for concern. While it may well be that this is a reaction to the Sarfu 2 test in recognizing that administrative officers require a different treatment, the manner in which this different treatment is advocated is such that it essentially condones administrative bias. This is the path towards diminishing public confidence in the administrative system. Public confidence in administration is as important as its confidence in the judiciary. The well-celebrated dictum of Lord Hewart L.C. in $R v$ Sussex Justices ex p. McCarthy ${ }^{84}$ that justice must not only be done but must be seen to be done, applies equally in my opinion to administrators. It is therefore on this ground that costs and expense should not be a reason for not disqualifying an administrative officer who is biased. If, in the process, an expensive inquiry is stopped, leading to great cost and inconvenience, so be it. The answer to concerns of cost and inconvenience is not to seek a change in the effect of review but to evolve rules that enable issues of recusal to be more easily detected administratively. In Hot Holdings, Kirby j adopted ${ }^{85}$ the opinion of Professor Carney that:

Public integrity as an ideal which must be nurtured and safeguarded, describes the obligation of all public officials to act always and exclusively in the public interest and not in furtherance of their own personal interests. ... [C]onduct less heinous than that of corruption may ... betray this trust. An example of this latter conduct is when a public official acts in the course of carrying out official duties in a way which also promotes his or her personal interests. Acting in this way, in the face of a conflict of interest between one's personal interest and the public interest, constitutes a betrayal of the public trust. But even if no betrayal in fact occurs, it taints the decision and the decision-maker with allegations of impropriety. The dangers posed for the public interest by the existence of conflicts of interest on the

$84 R$ v Sussex Justices ex p. McCarthy [1923] All ER 233.

$85 \quad$ N 31 par 156. 
part of public officials, whether the conflicts of interests are real or perceived to be real, demand the adoption of mechanisms which prevent such conflicts arising or which resolve them if they do arise. $^{86}$

It is submitted that the concerns of Professor Carney apply to administrators everywhere, including South Africa. Indeed, section 195 of the South African Constitution declares the basic values and principles governing public administration. Paragraph (d) thereof states that "services must be provided impartially, fairly, equitably and without bias." In this regard it may be necessary to achieve this goal by introducing a model as advocated above.

The possibility of curing by administrative appeal could also become a significant factor in the determination of a reasonable suspicion of bias. Thus a higher administrative officer or tribunal's determination of the matter could lead a court to conclude that there had been no bias. The recent recognition of Magistrates' Courts in the hierarchy of judicial review in the South African judicial system presents a good reason of assessing the jurisprudence of the European Court of Human Rights, especially as applied by English courts in determining whether to designate these courts as avenues for review as to facts of administrative action such that any administrative bias may be cured thereby. 


\section{Bibliography}

De Smith Judicial Review of Administrative Action 276

De Smith SA De Smith's Judicial Review of Administrative Action $4^{\text {th }}$ ed (Stevens \& Sons London 1980)

De Smith, Woolf and Jowell Judicial Review of Administrative Action 546-548 De Smith SA, Woolf $L$ and Jowell J Judicial Review of Administrative Action $5^{\text {th }}$ ed (Sweet \& Maxwell London 1995)

Devenish 2000 TSAR 397, 415

Devenish G "Disqualifying bias. The second principle of natural justice - the rule against partiality or bias (nemo iudex in propria causa)" 2000 TSAR 397,415

Forsyth 2001 CLJ 449

Forsyth C "Article 6(1) of the European Convention and the curative powers of judicial review." 2001 (60) CLJ 449

Forsyth 2003 CLJ 244

Forsyth C "Procedural Justice in Administrative Proceedings and article 6(1) of the European Convention on Human Rights and Fundamental Freedoms" 2003 CLJ 244

Garney 1991 Public Law Review 24

Garney G "The duty of parliamentarians to make ad hoc disclosure of personal interests" 1991 (2) Public Law Review 24

Kriel 1999 Annual Survey of South African Law 73

Kriel RR "Administrative Law" 1999 Annual Survey of South African Law 73

Malleson 2002 Legal Studies 56-57

Malleson K "Safeguarding judicial impartiality" 2002 Legal Studies 56-57 
Okpaluba 2003 JJS 109

Okpaluba C "Institutional independence and the constitutionality of legislation establishing lower courts and tribunals: Part 1" 2003 JJS (28) 109

Okpaluba 2004 TLR 1

Okpaluba C "Independence and impartiality as twin-pillars of the right to fair hearing: A review of Sole v Cullinan and Others" 2004 TLR 1 (1)

\section{Register of legislation}

Companies Act 61 of 1973

Constitution of the Republic of South Africa 1996

Promotion of Administrative Justice Act 3 of 2000

Promotion of Administrative Justice Amendment Act 53 of 2002

State Tender Board Act 86 of 1968

\section{Treaties and other international sources}

European Convention on Human Rights 1950

\section{Register of cases}

Absa Bank Limited v Hoberman [1997] 2 All SA 88

Adan v Newham London Borough Council [2002]1 WLR 2120

Afrox Ltd v Lata [1999] 5 BLLR 467 (LC)

Albert v Belgium (1983) 5 EHRR 533

AT/T v Saudi Cable Corporation [2000] 1 Lyold's Law Reports 22 (QB)

Baker v Canada (Minister of Citizenship and Immigration) [1999] 2 SCR 817

Bam-Mugwanya $v$ Minister of Finance and Provincial Expenditure, Eastern

Cape 2001 (4) SA 12 (Ck)

Bernstein v Bester NO 1996 (2) SA 751 (CC)

Bryan v UK (1995) 21 EHRR 342

BTR Industries South Africa (Pty) Ltd v Metal and Allied Workers Union (1992)

3 SA 673 (A)

Calvin v Carr and Others [1979] 2 All ER 440 (PC) 
Ciki v Commissioner of Correctional Services 1992 (2) SA 269 (E)

Claude Neon Ltd v City Council of Germistown 1995 (3) SA 710 (W)

Commissioner of Competition Commission v General Council of the Bar of

South Africa 2002 (6) SA 606 (SCA)

Committee of Justice and Liberty $v$ The National Energy Board [1978] 1 S.C.R.

369

Council of Review, South African Defence Force v Monnig and Others 1992 (3) SA 482(A)

County Fair Foods (Pty) Ltd v Theron NO [2001] 2 BLLR 134 (LC)

De Lille $v$ Speaker of the National Assembly 1998 (3) SA 340 (C)

Deumeland v Germany (1986) 8 EHRR 448

Dimes $v$ Proprietors of the Grand Junction Canal (1852) 3 HLC 759 [10 ER 301]

Dumbu v Commissioner of Prisons 19921 SA 58 (E)

Fedsure Life Assurance Ltd v Greater Johannesburg Transitional Metropolitan Council 1999 (1) SA 1 (CC)

Financial Services Board and another v Pepkor Pension Fund and another [1998] 4 All SA 129 (C)

Freedom of Expression Institute $v$ President of the Ordinary Court Martial 1999

BCLR $261(\mathrm{C})$

Hot Holdings Pty Ltd v Creasy [2002] HCA 51

Ighayiya Technical College $v$ Member of the Executive Council for Education,

Eastern Cape 1998 (4) SA 502 (Ck)

Janse van Rensburg v Minister of Trade and Industry 2001 (1) SA 29 (CC)

Kwazulu Transport (Pty) Ltd v Mnguni \& Others [2001] 7 BLLR 770 (LC)

Liebenberg v Brakpan Liquor Licensing Board 1944 WLD 52

Loggenberg $v$ Roberts 19921 SA 393 (C)

Lyold and Others v McMahon [1987] 1 All ER 1118 (HL)

Ma-Afrika Groepbelange (Pty) Ltd v Millman NO 1996 CLR 751 (C)

Mennitto v Italy (2002) 34 EHRR 1122

Minister for Immigration and Multicultural Affairs v Jia Leng (2001) 205 CLR 507

Minister of Justice $v$ Sapire (civ. App 49/ 2001, 10.6.02 unrep)

Mkhatswa v Mkhatswa 2002 (3) SA 441 (T) 
Moch v Nedtravel (Pty) Ltd t/a American Express Travel Service 1996 (3) SA 1 (A)

Nel v Le Roux NO 1996 (3) SA 562 (CC)

Newfoundland Telephone Company Limited $v$ The Board of Commissioners of

Public Utilities [1992] 1 R.C.S. 623

Parag v Ladysmith City Council 1961 (3) SA 714 (N)

Permanent Secretary, Department of Education and Welfare, Eastern Cape $v$ Ed-U-College (PE) (Section 21) 2001 (2) SA 1

President of the Republic of South Africa $v$ South Africa Rugby Football Union

(3) 2000 (1) SA 1 (CC)

President of the Republic of South Africa $v$ South African Rugby Football Union

(2) 1999(4) SA 147(CC)

$R$ (Alconbury) v Secretary of State [2001] 2 All ER 92

$R \vee$ Bow Street Metropolitan Stipendiary Magistrate and others ex parte Pinochet Ungarte (No. 2) [1999] 1 All ER 577

$R$ v Gaming Board for Great Britain: Ex parte Beniam and Khaida [1970] QB 417

$R$ v Gough (1993) 2 All ER 724

$R v$ Hereford and Worster CC, ex p Wellington Parish Council [1996] JPL 573

$R$ v Lippe 5 CRR (2d) 31

$R$ v Sussex Justices ex p. McCarthy [1923] All ER 233

R. v S. (R.D.) (1997) 118 CCC (3d) 353

Ringesien v Austria (No 1) (1971) 1 EHRR 425

Rose v Johannesburg Local Road Transportation Board 1947 (4) SA 272 (W)

Runa Begum v Tower Hamlets London Borough Council [2003] 1 All ER 731

$S$ v Roberts 1999 (4) SA 915 (SCA)

SACCAWU v Irvin \& Johnson Ltd (Seafoods Division Fish Processing) 2000 (3)

SA 705 (CC)

Sager v Smith 2001 (3) SA 1004 (SCA)

Salesi v Italy (1993) 26 EHRR 187

Schulte $v$ Van der Berg and others NNO 1991 (3) SA 717 (C)

Slade v Pretoria Rent Board 1943 TPD 131

Slagment v Building, Construction and Allied Workers' Union 1995 (1) SA 742

Sole $v$ Cullinan NO and others [2003] 3 All SA 466 (LesCA) 
Transnet Ltd v Goodman Bros (Pty) 2001 (12) SA 853 (SCA)

Umfolozi Transport (Edms) Bpk v Minister van Vervoer en andere [1997] 2 All SA 548 (A) 